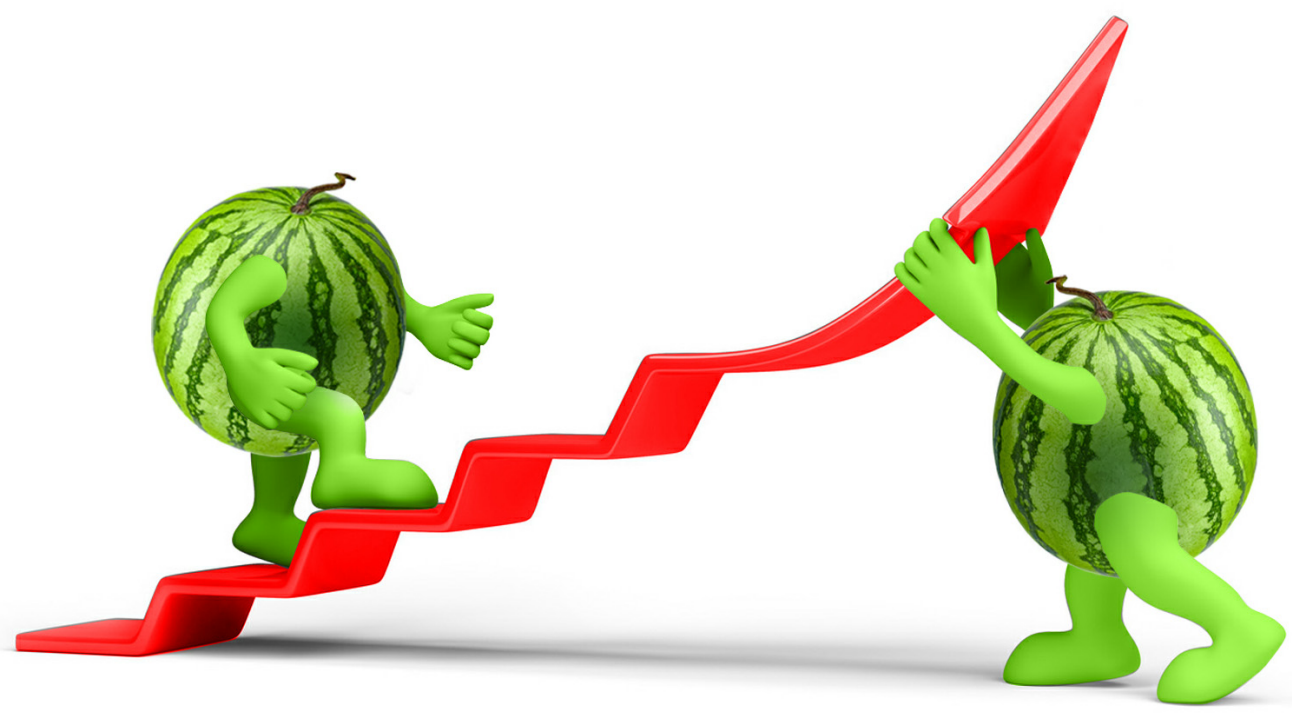

\title{
CONDITIONS AND DIRECTIONS OF MARKETING ACTIVITIES IN POLISH RESEARCH INSTITUTES
}




\section{S sciendo}

\section{CONDITIONS AND DIRECTIONS OF MARKETING ACTIVITIES IN POLISH RESEARCH INSTITUTES}

\section{dr Marlena Elżbieta Maślanka}

Institute for Engineering of Polymer Materials \& Dyes in Toruń

m.maslanka@impib.pl

DOI: 10.2478/minib-2019-0010

\section{Summary}

The offer of institutes is specific and requires the application of special solutions in the area of marketing and new economic conditions in which research institutes operate right now stimulate introducing new solutions and taking advantage of new directions in the area of marketing activity.

The influence of a continuous process of globalization on taking actions in the area of marketing constitutes a major research problem, which requires deepened, detailed analysis and carrying out research in this area. The goal of this article will be to find out to what extent new economic reality makes it necessary to take marketing actions and in what directions within the scope of this activity the research institutes should be going.

Keywords: globalization, restructuring, R\&D activity, marketing, research institutes 



\section{Introduction}

Research institutes in the contemporary global economy in an ever greater scope should react to changes and take actions aimed at strengthening and improving their image through intensification of marketing activities using new directions in this area. In the situation of Polish research institutes actions in the area of marketing didn't use to be taken for a long time and the implementation of these processes was delayed. The research-development sector in Poland has a long road in the history of functioning behind it and due to reliance on funds from the state it wasn't interested in marketing activities. It was only the processes of transformation and later globalization that in a significant way forced these entities to react and take marketing actions. Right now, in times of increasing competitiveness and emerging new directions in marketing research institutes should react and intensify actions in the area of marketing in order to strengthen their image, retain the current and acquire new markets for the offered products, including R\&D works. In light of the current, dynamically growing economy, without appropriate actions in this area research institutes may lose their position on the global market, or even stop functioning on the global market at all.

What also obliges research institutes to further boost their pace of development is the Strategy for Responsible Development till 2020, which points to the need to raise the innovativeness of the country and carrying out a far-reaching reform of the sphere of $R \& D$. In terms of innovativeness Poland occupies a distant place among European countries and for this reason it has to make a huge effort to reduce the distance. The road leading to the implementation of this goal is raising expenses on the sphere of $R \& D$ and carrying out a deep reform also in the area of marketing activity mainly in order to secure intelligent and sustainable development, which enables multiplying financial capital, technological and educational development.

The impact of advancing globalization on taking actions in the area of marketing constitutes a significant research problem which requires deepened, detailed analysis and carrying out research in this area. The goal of this article will be to determine in what scope new economic reality makes it necessary to start marketing activities and in what direction research institutes should move within the scope of this activity. 
The issues of transformation, globalization and the influence of these processes on the directions of development of research institutes constitutes a significant research problem, which requires deepened and detailed analysis and carrying out research in this area and it is these issues that this lecture will be devoted to.

\section{Globalization and the directions of marketing restructuring}

Globalization, according to a dictionary definition can be understood as a process started at the end of the 20th century in association with the popularization of electronic media, development of international corporations and the end of cold war. All of this contributed to the growth of turnover in international trade, intensification of the flow of capital, people and technologies, strengthening connections between countries and reducing cultural differences ${ }^{1}$.

Definition of the term globalization according to the dictionary Słownik Zarządzania i Finansów (Management and Finance Dictionary) - means: „proces upodabniania się gustów $i$ oferty produktu na catym świecie, wskutek czego popyt jest zaspokajany produktem globalnym, a nie lokalnymi"2. " (the process of assimilation of tastes and product offer in the whole world, so that demand is satisfied with a global, rather than a local product). Treating the definition of globalization in a more far-reaching way we should define this phenomenon as a process of formation of connections between particular regions, countries, continents reflected by international flows of capitals, technology, finances, commodities, information between the participants of the process. This is a process taking place in most companies of the world. The clients for the products of these companies are found everywhere, where there are industrial recipients, regardless of the country borders separating them.

The term globalization is a concept used very often and eagerly both in scientific literature and in colloquial language. However, we seldom stop to think what in reality the word globalization means and whether there is one coherent definition of this phenomenon. William Scheuerman, the author of the entry "Globalization" in Stanford Encyclopedia of Philosophy claims that the term covers a broad range of diversified political processes 
and phenomena existing in the contemporary world. The term of globalization also replaced other, earlier used words, which defined phenomena and processes covering with their scope more than one country ${ }^{3}$ According to Scheuerman, the popular meanings of the term globalization cover various phenomena and most often they are:

- increasing domination of western forms and models of political, economic life, or in other words, westernization, or americanization of life in various parts of the world, outside economically developed countries;

- increasing number and efficiency of new inventions and means of communication thanks to more and more advanced information technologies; Scheuerman calls this phenomenon the Internet Revolution;

- finally, the term globalization is often used to define social situation, mainly in developed countries, where advanced integration processes are leading to the formation of a uniform society in which internal conflicts and barriers are disappearing; this is a symptom of a "global integration".

The concept of "globalization" is closely tied to global economy, that is, an economy in which the production factors - natural resources, capital, technology and workforce - as well as products and services circulate around the whole world. For the first time everything can be produced and sold anywhere in the world. In economy this means production of every component and carrying out every activity in such a place in the world, where it is possible to do it at the lowest cost and where prices and profits are the highest ${ }^{4}$.

The definition of the concept of globalization is associated with according to Richard Koch - the term of glocalization of organizations, which is a combination of the words global localization ${ }^{5}$. The goal of glocalization is transforming a company so that it is able to react to the needs of clients in the whole world in a flexible way and so that its structure makes it easier for the global client to engage in business relations with a company ${ }^{6}$.

At the same time marketing in the era of globalization and economy based on knowledge has a lot to offer in the conceptual layer and this is the result of development of various streams of the concept of marketing at the end of the 20 th and the beginning of the 21 st century. It is worth recalling 
here that marketing in its original form is a projection of the marketing activity of a particular company, or its specialized part based on the ideological assumptions of marketing, which covers the goals of activity, general guidelines concerning the ways of achieving them and composition of the instruments of influence.

In times of globalization mutual cooperation of the sector of companies and the sector of science is necessary. What is necessary in contemporary economy is the model of choice of strategy and innovation policy. The model should be based on the achievements of the public R\&D sector and strong potential of innovative companies and it is typical of a small group of modern economies of the world such as United States, Japan, Germany, Finland, or Sweden. The essence of this model is focus on the development of national technological abilities and creating institutions stimulating cooperation in the state - industry - R\&D sphere setting. The implementation of this strategy requires high spending on R\&D activity financed by both the public and the private sector.

The propositions of innovative strategy and cooperation in course of research-development activity conducted by the industry presented in a subsection are an example for adaptation in Polish industry. This is necessary, if the sector of science is supposed to engage in innovative activity. We should reach for already tested models for building centres based on cooperation in the conducted research-development activity between the industry and the R\&D sphere.

Analyzing this problem it is necessary to point out that in times of globalization cooperation with the industry, as well as introducing innovations, is actually a requirement for further efficient operation of the researchdevelopment sphere. Thus, it is necessary to take appropriate measures aimed at raising funds for these purposes and in the first place carrying out changes in the research-development sector, including the area of marketing.

Undoubtedly, globalization opens up new possibilities for economic success of countries undergoing transformation, for catching up with the currently richest countries of the world. To make it possible it is necessary to apply a wise, national strategy of development based on the development of innovativeness and economy based on knowledge.

Globalization creates additional opportunities for solving this problem through access to financial centres, absorption of foreign direct investments, 
transfer of innovations and knowledge. Foreign direct investments, transfer of innovations are the most certain way to raising competitive abilities and the development of the research-development sector.

New economy brought the emergence of a new concept of marketing based on knowledge implemented mainly within network organizations. This kind of marketing requires many adequate resources and consciously built competences. New economy has three features: it is global, it favours non-material entities and it is highly connected internally.

To apply the concepts of marketing in research institutes it is necessary to carry out the processes of their restructuring in three main areas as:

1. Market reorientation of a Research Institute.

2. Product restructuring within the scope of conducted researchdevelopment works.

3. Changes in sales of products and $R \& D$ services with the application of marketing-mix tools.

The goal of marketing restructuring is expansion and activation of the market functions of research institutes, leading above all to raising sales and strengthening their market position, understood as key factors necessary for their development.

It is worth pointing out that in the conducted restructuring ventures the formation of an appropriate orientation of an institute plays a particular role. Market reorientation of an institute means in the long term changing its philosophy of operation, which involves shifting the focus of functioning from generation of services and products to effective sales of services and products. Such an attitude represented by an Institute has its particular practical dimension - it influences the strategy and tactics of operation of a scientific unit, defining its goals, instruments and conditions for implementation. At the same time product restructuring covers transformations among which we can distinguish comparably simple changes in the product offer of a unit, restructuring in the product-market setting and changes concerning the scope of the offer, or even completely changing the former domain of activity. The first, comparably simple stage of product restructuring concerns changes in Institutes' offer, including the scope and way of carrying out research-development works aimed at: 
- raising production and sales of goods generating most of the revenues of Institutes,

- abandoning research products and services which are unprofitable and outdated, which have no prospects on the market.

Restructuring in the product - market setting (changes in sales) and new utilization of marketing-mix tools constitutes the deepening of simple changes in the Institutes' offer. Actions in this area are associated with marketing strategy and exert influence on the assumptions of the strategy of development of a whole unit. The main goal of restructuring at this stage is raising the sales of research works and services of a unit through closer connection with the character, size and distribution in space and time of the needs satisfied by the unit.

What constitutes the basis of such activities is detailed identification of the needs of buyers in the categories of actual and potential demand, as well as carrying out a market segmentation. The final task carried out in this setting is defining the target markets (segments) and thus, final recipients of the offer of a unit and this way adopting a programme of marketing activities taking into consideration the optimum product-market combinatio $^{7}$. The best way to present the area of restructuring measures in the product - market setting is modified Ansoff matrix, as shown in table 1.1.

Table 1.1. The area of restructuring activities in the product - market setting

\begin{tabular}{l|c|c|c}
\hline \multicolumn{1}{c|}{ market } & existing market & expanded market & new market \\
product & 1 & & \\
existing product & & & \\
changed product & 3 & & \\
new product & & & \\
\hline
\end{tabular}

Source: L. Garbarski, I. Rutkowski, W. Wrzosek, Marketing. Punkt zwrotny nowoczesnej firmy, PWE, Warszawa 1998, p. 155.

For the purpose of more detailed analysis and proper interpretation of table number 1.1 the explanations of particular elements contained in table 1.1 in the product - market setting are shown in table 1.2. 
Table 1.2. The area of restructuring activities in the product - market - supplementation setting

\begin{tabular}{|c|c|c|c|}
\hline $\begin{array}{c}\text { Concentration of } \\
\text { restructuring activities in } \\
\text { the setting of existing } \\
\text { markets, products and } \\
\text { services }\end{array}$ & $\begin{array}{l}\text { Entering new markets } \\
\text { with existing r\&d } \\
\text { products and services }\end{array}$ & $\begin{array}{l}\text { Development of the offer } \\
\text { and placing new r\&d } \\
\text { products and services on } \\
\text { existing markets }\end{array}$ & $\begin{array}{l}\text { Entering new markets } \\
\text { with new research } \\
\text { products and services } \\
\text { (innovations) }\end{array}$ \\
\hline $\begin{array}{l}\text { - intensification of existing } \\
\text { ventures and solutions } \\
\text { aimed at raising sales of } \\
\text { previously offered R\&D } \\
\text { products and services to } \\
\text { the same buyers, } \\
\text { - raising the penetration of } \\
\text { the market, } \\
\text { - greater diversification of } \\
\text { prices, intensification of } \\
\text { promotion, active } \\
\text { formation of the } \\
\text { distribution channels. }\end{array}$ & $\begin{array}{l}\text { - possession of an } \\
\text { attractive, competitive } \\
\text { offer by Research } \\
\text { Institutes, } \\
\text { - entering international } \\
\text { markets, exports. }\end{array}$ & $\begin{array}{l}\text { - formulating basic goals for } \\
\text { the development of } \\
\text { Research Institutes and } \\
\text { defining target market } \\
\text { segments, } \\
\text { - modernization of the } \\
\text { manufacturing base of } \\
\text { Research Institutes } \\
\text { (technological } \\
\text { restructuring). }\end{array}$ & $\begin{array}{l}\text { Creating conditions of } \\
\text { development taking } \\
\text { into consideration the } \\
\text { trends towards } \\
\text { globalization of markets } \\
\text { and the activities of } \\
\text { Research Institutes.. }\end{array}$ \\
\hline
\end{tabular}

Source: : Own materials prepared on the basis of: C. Suszyński, Restrukturyzacja przedsiębiorstw, PWE, Warszawa 1999, p. 140.

Information presented in tables 1.1 and 1.2 constitute an attempt to create an optimum model of restructuring of a research institute depending on the combination of the market - product setting. Thus, it is possible to conclude that marketing restructuring constitutes one of most important changes in research institutes, which is associated the most with continuously advancing globalization of markets and the current global economic crisis.

The main reason for such strong position of marketing restructuring within the general restructuring process is the contemporary orientation of research institutes focused on what is emphasized the most in modern marketing: identifying and satisfying the client's needs. 


\section{Research assumptions}

The goal of research and analysis will be finding out in what scope new economic reality stimulated changes in the area of marketing of research institutions and highlighting the directions of actions taken within this area.

In association with the goal which in a general way defines the directions of deliberations, the following research problem has been formulated under conditions of growing inclination towards globalization the directions of changes in marketing head for raising the competitiveness of Research Institutes, raising the usefulness of R\&D activity and the transfer of knowledge.

\section{Research methodology and characteristics of the research sample}

Empirical research contained in the scope of the formulated research assumption was conducted on a group of 34 research institutes, which responded to the sent questionnaire. The questionnaire survey was conducted from August to October 2016 and it involved sending the questionnaire to 55 research institutes supervised by the Ministry of Development. The goal of the survey was obtaining information necessary for the verification of the assumed research problem and allowing the expansion of the current state of knowledge about the directions of marketing activities, as well as about the necessary processes of restructuring in the area of marketing.

Picture 1.1 presents the structure of the survey sample, according to the scientific category ${ }^{8}$. 
Picture 1.1. The structure of surveyed Institutes, according to scientific category

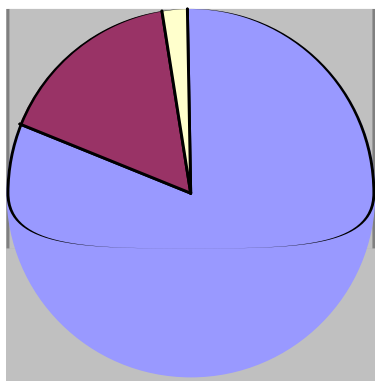

$$
\begin{aligned}
& \text { D 1.Category }(B) \\
& \square \text { 2.Category } \\
& \text { a } 3 . \text { Category } \\
& \text { (C) }
\end{aligned}
$$

[1] - Category of the quality of research-development activity B $-81 \%$

[2] - Category of the quality of research-development activity A $-17 \%$

[3] - Category of the quality of research-development activity $\mathrm{C}-2 \%$

Source: Own materials prepared on the basis of the results of questionnaire surveys.

Most of the surveyed Institutes declare they have category B, which may show that understanding of the necessity to intensify the focus of their activities on provision of research-development services is growing.

The following picture 1.2 presents the structure of the research sample, according to the area of research activity.

Picture 1.2. The structure of research institutes, according to the area of research activity

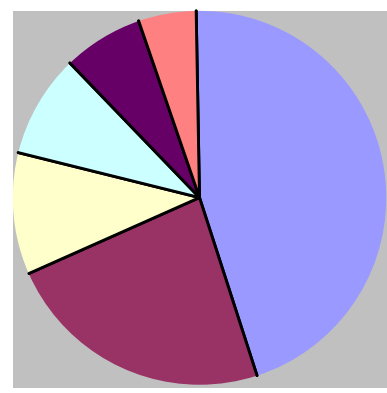

[1] - chemical sciences - $46 \%$

[2] - technical sciences $-24 \%$

[3] - medical sciences $-10 \%$

[4] - environment engineering and protection $-8 \%$

[5] - natural sciences - 7\%

[6] - others $-5 \%$

\begin{tabular}{|l|}
\hline 1.Chemical sciences \\
$\square$ 2.Technical sciences \\
$\square$ 3.Medical sciences \\
4.Environment \\
engineering and protection \\
5.Natural sciences \\
$\square$ 6.Others
\end{tabular}

Source: Own materials prepared on the basis of the results of questionnaire surveys. 
Most institutes declare that they conduct research in the area of chemical sciences, technical, medical sciences, as well as sciences from the area of environment protection and engineering, which suggests that most of the important areas of Institutes' scientific activity are present in the surveyed group.

What is important from the point of view of activity conducted by the Institutes is that $100 \%$ of them declared their type of activity is registered as PKD 7219Z, which means that research-development (R\&D) activity is the basic activity of the surveyed units.

\section{Summary and conclusions}

The presented deliberations made it possible to determine the most important directions of marketing activities in research institutes and led to the following conclusions:

For the needs associated with the verification of this hypothesis it is necessary to carry out an analysis of the degree of progress of marketing activities with a division into particular, highlighted directions of these activities in the area of marketing. What is apparent is also different intensity of particular activities in each of the distinguished directions of marketing activities. The results of research concerning this problem are presented in table 1.3.

On the basis of the data presented in table 1.2 it is possible to conclude that in the processes of changes in Polish research institutes within particular directions of marketing the intensity of taken measures differed in time. Introduction of changes started with the implementation of ventures which involved the change of a marketing strategy and above all making the community of Institutes realize the necessity to intensify activities in the area of marketing. Afterwards — as research suggests — further, specified directions of marketing activities were carried out. Processes of activities can be recognized as almost complete in the area of marketing strategies (86\% of responses) and raising employees' awareness in this area (57\% of responses), activities which involve the application of marketing based on knowledge (30\% of responses), promotion in the media (91\%) and diversification of activity (25\% of responses). Research results prove that research institutes are undergoing intensive changes in the area of marketing and new directions in the area of marketing for most Institutes are not an alien process, which is only starting. 
Table 1.3. The degree of progress of the directions of marketing activities

\begin{tabular}{l|c|c}
\hline \multicolumn{1}{c|}{ Directions of marketing activities } & $\begin{array}{c}\text { Carried out } \\
\text { in full* }\end{array}$ & $\begin{array}{c}\text { The process of } \\
\text { implementation } \\
\text { has been started * }\end{array}$ \\
\hline $\begin{array}{l}\text { 1. Change of marketing strategy (preparing restructuring } \\
\text { programmes for a unit and long-term marketing programmes) }\end{array}$ & $86 \%$ of responses & $14 \%$ of responses \\
$\begin{array}{l}\text { 2. Preparing new marketing strategies and raising awareness } \\
\text { in the area of application of marketing by the employees } \\
\text { of a Research Institute }\end{array}$ & $57 \%$ of responses & $43 \%$ of responses \\
$\begin{array}{l}\text { 3. Promotional activities which involve marketing based on knowledge } \\
\text { (growth of the prestige of a Research Institute, access to the database } \\
\text { of R\&D projects, clients, patents, publications) }\end{array}$ & $30 \%$ of responses & $70 \%$ of responses \\
$\begin{array}{l}\text { 4. Tactical activities which involve the growth of competitiveness } \\
\text { of Research Institutes through the development of new offer, } \\
\text { including R\&D (diversification) }\end{array}$ & $25 \%$ of responses & $75 \%$ of responses \\
$\begin{array}{l}\text { 5. Traditional marketing, among others, advertising in the media, } \\
\text { information brochures, bulletins, gadgets etc. }\end{array}$ & $91 \%$ of responses & $11 \%$ of responses \\
$\begin{array}{l}\text { 6. Creating so-called marketing networks, that is, all direct and indirect } \\
\text { relations with market entities perceptible from the perspective } \\
\text { of Research Institutes (new opportunities for cooperation) }\end{array}$ & $9 \%$ of responses & $91 \%$ of responses \\
$\begin{array}{l}\text { 7. Greater focus on the market and changing the philosophy of activity, } \\
\text { the engagement of other departments of Research Institutes } \\
\text { in marketing (R\&D, Administration, finances) }\end{array}$ & $5 \%$ of responses & $95 \%$ of responses \\
\hline
\end{tabular}

*\% indicators are rounded up to whole figures.

Source: Own materials prepared on the basis of questionnaire surveys.

Apart from the presented research results it is necessary to present further data resulting from the structure of answers to the question concerning the identification of the most important marketing activities conducted in particular years. The data are presented in table 1.4.

Data presented in table 1.4 show that in particular periods it is possible to notice the phenomenon of diversification of the intensity of implementation of changes in the area of marketing. As the above comparison suggests, what has been recognized as the most important and the earliest started direction of changes is traditional form of marketing, among others, advertising in the media, information booklets, brochures, gadgets. Thus, the implementation of changes in the area of this traditional practice confirms the importance of marketing activities in Polish research institutions. 
Table 1.4. Intensity of marketing activities carried out in the surveyed institutes in the years 2014-2016

\begin{tabular}{l|c|c|c}
\hline \multicolumn{1}{c|}{ Directions of marketing activities } & $\mathbf{2 0 1 4}$ & $\mathbf{2 0 1 5}$ & $\mathbf{2 0 1 6}$ \\
\hline $\begin{array}{c}\text { Change of marketing strategy (preparing restructuring } \\
\text { programmes for a unit and long-term marketing programmes) }\end{array}$ & $10 \%$ of responses & $10 \%$ of responses & $20 \%$ of responses \\
$\begin{array}{c}\text { Preparing new marketing strategies and raising awareness } \\
\text { of the necessity of application of marketing by the employees } \\
\text { of Research Institutes }\end{array}$ & $15 \%$ of responses & $12 \%$ of responses & $18 \%$ of responses \\
$\begin{array}{l}\text { Promotional activities which involve the introduction } \\
\text { of marketing based on knowledge (growth of prestige } \\
\text { of Research Institutes, access to the database of R\&D projects, } \\
\text { clients, patents, publications) }\end{array}$ & $12 \%$ of responses & $19 \%$ of responses & $19 \%$ of responses \\
$\begin{array}{l}\text { Tactical activities which involve the growth of competitiveness } \\
\text { of Research Institutes, raising strength through the } \\
\text { development of new offer, including R\&D (diversification) }\end{array}$ & $15 \%$ of responses & $17 \%$ of responses & $20 \%$ of responses \\
$\begin{array}{c}\text { Advertising in the media, information brochures, bulletins, gadgets } \\
\begin{array}{c}\text { Creating so-called marketing networks, that is, all direct and } \\
\text { indirect relations with market entities perceptible from the } \\
\text { perspective of Research Institutes (new opportunities for } \\
\text { cooperation) }\end{array}\end{array}$ & $10 \%$ of responses & $25 \%$ of responses & $29 \%$ of responses \\
$\begin{array}{c}\text { Greater focus on the market and change of the philosophy of } \\
\text { functioning and engaging other departments in marketing } \\
\text { (R\&D, Administration, finances) }\end{array}$ & $15 \%$ of responses & $19 \%$ of responses \\
\hline
\end{tabular}

*\% indicators have been rounded up to full figures.

Source: Own materials prepared on the basis of questionnaire surveys.

Moreover, the presented results of empirical research show that introducing changes in the area of marketing is a continuous process and its implementation required division into particular directions in terms of the "importance" of their implementation — in Polish research institutes. For this purpose gradation of particular directions of marketing activities was carried out. The processes of changes in the areas of particular directions of activities were particularly intensive in 2016 .

The start of changes in the area of marketing in research institutes was caused by defined factors whose strength and intensity of influence depended on the phenomena taking place in the Polish economy, that is, globalization. These factors influenced (or forced) making decisions to start 
particular marketing activities, starting from analysis, diagnosis of the situation, as well as detailed planning of the directions of marketing activities. At the same time the results show that research institutes apply both the concept of classic, strategic, relational marketing, as well as marketing based on value. Two kinds of effects are generated: those associated directly with the activity of research institutes (profit, value of a unit, brand value, revenues) and results associated with the client (client satisfaction, value for the client).

Activities in the area of marketing should involve mainly promotion of an Institute in the area of research works which have already been implemented, or are being implemented (among others, databases). It is research-development works as a real "product" of the activity of an Institute that determine its value, which should be promoted, "sold", and provided to a possibly broadest group of recipients. It is the commercialization of science that led to a situation in which all Institutes started being regarded in terms of marketing. To function and develop it is necessary to attract the client by informing about and promoting your products. The changes taking place in contemporary media enforce the introduction of significant modifications in, among others, communication with the recipients. These changes will concern both the utilization of the forms of informing about and advertising activities and achievements, as well as manner and language of messages addressed to various groups of recipients. New media have brought a broad range of possibilities of reaching the recipients interested in particular subject and facilitating the system of communication with them. Internet websites have become an exceptionally popular form of marketing activity, that's why it is so important for Institutes to take care of their Internet websites, to make sure that they are regularly updated with new information about available services, conducted research-development works and that they provide necessary information about the current events concerning institutes.

In association with the above, it is above all the following things that should be used as efficient means of promotion of science and research of institutes:

- Internet as one of the most important media for promotion of science in the world, including mainly: Internet websites presenting institutes and 
their offer of research, electronic mail, ICT network for external and internal communication of an Institute, monitoring the Internet and updating knowledge, information-promotion tool making it possible to reach target groups, cooperation with thematic portals, links and information about conducted projects and project partners, information about the availability of all publications.

- Institutes' own materials including: reports about achievements including plans of research and spending on the implementation of these plans, publications presenting institutes (brochures), posters promoting a given scientific field, bulletins (newsletters) printed, or distributed over the Internet.

- Expanding the activity of the units of Scientific Information operating in institutes, which would be responsible for the organization of the system of provision of information, visual identification of particular institutes, contacts with the media, contacts with the environment, including social-business environment, they would also inform about the announced contests for the implementation of research-development works9.

In light of this the most important task that research institutes should deal with should be working out a system of communication with the environment, which will become a "conveyor belt" for informing and dissemination of scientific achievements and conducted research, as well as for establishing cooperation with business. As a result, such actions should efficiently support the transfer of knowledge and commercialization of the results of research conducted in Institutes.

The main marketing task of the managers of particular units should be maintaining relationships with the already existing clients and penetration of the market for the identification of potential clients - appropriate offers should be prepared for them. Only very active marketing with the utilization of all available channels of marketing communication can support the implementation of the statutory goals of research institutes. In the opposite case clients won't have knowledge about the research conducted by institutes and will have hampered access to their results, their popularization will be insufficient, the ability to build new research teams will be low (especially in case of interdisciplinary research). 
It is possible to say that in an institute marketing activities are conducted by everyone who published anything on paper, or by means of Internet websites, or appear at conferences, seminars etc. Such active marketing will also make it possible to promote institutes, thus, it is necessary to efficiently activate these actions and encourage scientific employees to engage in such promotion.

Research institutes have a big potential, they have big resources of knowledge. Unfortunately, this is often not associated with the "sale" of products, or services from conducted research-development activity and this activity is often marginalized. As a result, this may lead to a situation in which institutes will be "excluded" from this activity and will be unable to operate on the commercial market as scientific units, especially if the potential recipients of knowledge (e.g. companies) feel the lack of their offer, or rather, feel the inability to reach exactly such offer ${ }^{10}$.

New reality in which research institutes are important participants obliges them to continuously pursue the processes of adaptation and it is necessary to restructure them highlighting the directions of these activities. Research institutes are actively looking for their place between other scientific units with an educational mission, while what is closest to the mission of institutes is looking for and creating new technologies and new knowledge.

Summing up the results of conducted surveys it is possible to conclude that the problems of conditions and directions of marketing activities of research institutes in this area of marketing in the years 2014-2016 are an exceptionally complex issue. Directions of activities in the area of marketing are changing dynamically. New tools, new needs, necessity to conduct dialogue with the recipients require analysis and evolution, strategy and marketing programmes which will help institutes in the process of adaptation to the market system .

In light of the above deliberations globalization encourages taking radical measures in the area of marketing activities, above all, aimed at creating marketing networks, switching orientation to the market and changing the former philosophy of activity in the area of marketing. 


\section{References}

${ }^{1}$ See: Stownik wyrazów obcych, Wydawnictwo Naukowe PWN, Warszawa 2006, p. 332.

${ }^{2}$ R. Koch, Stownik Zarzadzania i Finansów. Narzędzia, terminy, techniki od A do Z, Wyd. Profesjonalnej Szkoły Biznesu, Kraków 1997, p. 76.

${ }^{3}$ See: M. Czerny, R. Łuczak, J. Makowski, Globalistyka. Procesy globalne i ich lokalne konsekwencje, Wyd. Naukowe PWN, Warszawa 2007, p. 23.

${ }^{4}$ See: L. C. Thurow, Przyszłość kapitalizmu, Wyd. Dolnośląskie, Wrocław 1999, p. 157-220.

${ }^{5}$ See: R. Koch, op. cit., p. 77.

${ }^{6}$ See: Tamże, p. 77.

${ }^{7}$ L. Garbarski, I. Rutkowski, W. Wrzosek, Marketing. Punkt zwrotny nowoczesnej firmy, PWE, Warszawa 1998, p 155 .

${ }^{8}$ Art. 42 ust. 3 Ustawa z dnia 30 kwietnia 2010 r. o zasadach finansowania nauki. Dz.U. 2010, Nr 96, poz. 615. . (Act on the rules of financing science) As a result of complex assessment of the quality of scientific, or researchdevelopment activity, scientific units are assigned a category: A+ (leading level), A (very good level), B (satisfactory level with a recommendation for strengthening scientific activity, research-development activity, or activity stimulating the innovativeness of the economy), C (unsatisfactory level). Parametric assessment means an assessment of the activity of a scientific unit taking into consideration the results of scientific activity, practical applications of the results of scientific research and development works, as well as other kinds of activity of a scientific unit.

${ }^{9}$ W. Wiśniowski, Marketing Instytucji Naukowych i Badawczych. Prace Instytutu Lotnictwa nr 208, Wydawnictwo Naukowe Instytutu Lotnictwa, Warszawa 2012, p. 13-19.

${ }^{10}$ Ibidem, p. 51-57.

${ }^{11}$ W. Wiśniowski, Marketing Instytucji Naukowych i Badawczych, Wydawnictwo Naukowe Instytutu Lotnictwa, Warszawa, 2012, p. 10.

\section{Bibliography}

1. Altman, R. (2009). The Great Crash 2008. Foreign Affairs, Vol. 88, No 1.

2. Garbarski, L., Rutkowski, W., Wrzosek, W. (1998). Marketing Punkt zwrotny nowoczesnej firmy. Warszawa: PWE.

3. Landler, M. (2008). West Is in Talks on credit to Aid Poorer Nation. The New York Times.

4. Mishkin, F. (2000-2007). The Economics of Money. Banking, and Financial Markets. The Addison-Wesley. Overview of the GSEs'Housing Goal Performance.

5. Sors, G. (1999). Kryzys światowego kapitalizmu. Warszawa: Muza S.A.

6. Tofler, A. (1977). Ekospazm. Warszawa: Czytelnik.

7. Wiśniowski W. (2010). Marketing Instytucji Naukowych i Badawczych. Prace Instytutu Lotnictwa $n r$ 208, Warszawa: Wydawnictwo Naukowe Instytutu Lotnictwa.

8. Wiśniowski, W. (2012). Marketing Instytucji Naukowych i Badawczych. Prace Instytutu Lotnictwa, Warszawa: Wydawnictwo Naukowe Instytutu Lotnictwa.

9. Act from July 25, 1985 about research-development units: Dz.U. 2008, Nr 159, poz. 993 z późn. zm.

10. Act from April 30, 2010 - Regulations introducing laws reforming the system of science. Dz.U. 2010, Nr 96, poz. 620 z późn. zm..

11. Act from October 8, 2004 about the rules of financing science: Dz.U. 2008, Nr 169, poz. 1049 z późn. zm.

12. Act from April 30, 2010 about research institutes. Dz.U. 2010, Nr 96, poz. 618 z późn. zm. 
Marlena Elżbieta Maślanka, Polska - doctor of economic sciences, specialized in the area of management and accounting. Currently she is the Director of Instytut Inżynierii Materiałów Polimerowych i Barwników (Institute of Polymer and Pigment Engineering) in Toruń. She has been cooperating with the Institute for over ten years. Work in a Research Institute and direct participation in a restructuring process carried out in the Institute became an inspiration for her to start scientific activity and write a doctoral thesis concerning the conditions and directions of restructuring of Research Institutes in Poland. As a result, since 2008 she has been developing her scientific interests along with professional career. 